\title{
Organdonasjon og samfunnets verdier
}

Transplantasjon er en integrert del av behandlingstilbudet for visse organsykdommer. Det forutsetter organdonasjon, fra både levende og døde. Behovet for organer er større enn tilbudet, og det er en målsetting å øke tilgangen. Transplantasjonslovens dødsbegrep er hjernedød. Gjeldende praksis er at man overfor pårørende reiser spørsmålet om donasjon når behandlingsmulighetene er uttømt og hjernedød er nær forestående eller et faktum. Kunne noen av vilkårene i transplantasjonsloven endres slik at organdonasjon kunne bli lettere å få gjennomført? Endringsforslag måtte uansett bygge på at ingen ønsker utrygghet omkring hvorvidt sykehuslegene ved livstruende skade/ sykdom prioriterer virksom behandling foran organdonasjon.

Hvilke holdninger har norske leger til avsluttende behandling og organdonasjon? Dette er Foss og medarbeideres problemstillinger i dette nummer av Tidsskriftet (1). De gjennomførte i 2008-09 en spørreskjemaundersøkelse blant leger ved intensivavdelinger og spesialister og utdanningskandidater i nevrokirurgi. 435 leger $(55 \%$ av mottakerne) returnerte spørreskjemaet. 315 av 420 svarte at de kunne tenke seg å starte organbevarende behandling «når det ikke finnes håp for pasienten», mens $18 \%$ var i tvil og $7 \%$ svarte at de ikke kunne tenke seg dette.

Forfatterne benytter begrepet «når det ikke finnes håp». Det kan være mange forhold i forløpet av kritisk hjerneskade/-sykdom som fratar helsepersonell og pårørende håp. For behandlingsansvarlig lege dreier det seg ikke om håp, men om avklaring av behandlingsmuligheter og den kritiske sykdomsutviklingens videre forløp. Forfatterne har ikke drøftet sine resultater i lys av de forslag som ble fremmet i den offentlige utredningen Når døden tjener livet fra 2011 (2).

I utredningen ble det belyst hvorvidt konvensjonell cerebral angiografi fortsatt skulle være eneste radiologiske metode for diagnostikk av opphørt cerebral sirkulasjon. Også hjerte- og åndedrettsstans som kriterium for død før organdonasjon ble gjennomgått. Ett av forslagene var at loven skulle gi adgang til å iverksette organpreserverende behandling (intensivbehandling) ved alvorlig hjerneskade-/ sykdom selv om det ikke var grunnlag for å iverksette livreddende behandling. Praksis er vanligvis å iverksette organpreservasjon etter at livreddende behandling er fors $ø$ kt.

Det kan skape vansker for behandlende lege å forklare de pårørende til en pasient med livstruende hjerneskade-/sykdom at man ikke finner grunnlag for å sette i gang behandling, men at man gjerne vil iverksette tiltak for å bevare og bruke pasientens organer. Ved Oslo universitetssykehus pågår det et prosjekt der forutsetningen for organdonasjon ikke er hjernedød, men alvorlig hjerneskade/-sykdom med inntruffet hjerte- og åndedrettsstans ved behandlingsavslutning.

Organdonasjonsarbeidet $i$ en intensivavdeling krever store ressurser. En organdonasjonskandidat kan tenkes å fortrenge en annen alvorlig syk pasient. Økt vektlegging av organpreservasjon og dermed transplantasjonsaktivitet vil måtte kreve ressurser.

Det har nok ikke vært intensjonen i noen instans å redusere donors integritet som pasient. Dog vil forslagene fra utredningen Når døden tjener livet kunne skape uklarhet. Helse- og omsorgsdepartementets nylige antydning om mulig fremtidig legalisering av aktiv dødshjelp (3) bidrar i denne retning. Departementet foreslo i et høringsnotat om fastlegenes reservasjonsrett vedrørende henvisning til abort en tilføyelse i helse- og omsorgstjenesteloven $\S 3-2$. Tilføyelsen skulle hjemle forskrift om mulighet for fastleger til å reservere seg ved alvorlige samvittighetskonflikter, deriblant «reservasjon mot aktiv dødshjelp dersom dette skulle bli tillatt» (3).
I enkelte land er aktiv dødshjelp ytt av lege tillatt (4). Dog innebærer ikke dette at leger har plikt til å medvirke. Lovhjemlet rett (også for sykehusleger) til å reservere seg mot aktiv dødshjelp skulle det vel bare bli behov for dersom legen kunne bli pålagt å yte slik hjelp. Aktiv dødshjelp er tiltenkt andre pasientgrupper enn dem vi behandler i en intensivavdeling. Men ikke utelukkende - det er avhengig av mulige retningslinjer for aktiv dødshjelp. Ytterst få intensivleger ville støtte aktiv dødshjelp. Kunne det likevel forstyrre forholdet mellom lege og pårørende $\mathrm{i}$ en intensivavdeling med donasjonsoppgaver hvis aktiv dødshjelp var tillatt?

Avsluttende behandling må være basert på tillit. En forutsetning er forståelig og dekkende informasjon til pasient og pårørende. Det må ikke kunne oppstå tvil om at legens rolle er å behandle pasienten (5). Avsluttende behandling skal skje etter etablerte retningslinjer (6). Organdonasjon skal ikke konkurrere med behandlingsformålet, men vil inntre som en mulighet der behandling ikke har ført frem og pasienten er døende/død. Lovforslag som i større grad åpner for organpreservasjon med sikte på donasjon når livreddende behandling er formålsløs, men ikke forsøkt og pasienten med stor sikkerhet vil dø snarlig, forutsetter en ny forskrift med balansering av de nevnte hensyn.

Helse- og omsorgsdepartementet arbeider på en revisjon av transplantasjonsloven med utgangspunkt i forslagene i den offentlige utredningen fra 2011 (2). En ny forskrift som åpner for alternativ til konvensjonell angiografi ved diagnostikk av hjernedød er ventet (7). Endringsforslagene vil trolig utløse debatt. Selv om høringsnotatet om reservasjon ble trukket tilbake, har departementet utilsiktet skapt uklarhet omkring behandlende legers fremtidige rolle i avsluttende behandling - som i enkelte tilfeller vil kunne bli relatert til organdonasjon (3).

\section{Rolf Hanoa}

rohano@online.no

Rolf Hanoa (f. 1944) er professor emeritus i sosialmedisin og i helseadministrasjon, spesialist i karkirurgi og overlege ved Nevrokirurgisk avdeling, Oslo universitetssykehus. Han er professor II i arbeidsmedisin ved Universitetet i Bergen.

Forfatter har fylt ut ICMJE-skjemaet og oppgir ingen interessekonflikter.

\section{Litteratur}

1. Foss S, Sanner M, Mathisen JR et al. Legers holdning til organdonasjon. Tidsskr Nor Legeforen 2014; 134: 1142-5

2. Norges offentlige utredninger. Når døden tjener livet. Et forslag til nye lover om transplantasjon, obduksjon og avgivelse av lik. NOU 2011: 21

3. Helse- og omsorgsdepartementet. Høringsnotat. Hjemmel til å gi forskrifter om reservasjonsmulighet for fastleger... Oslo: Helse- og omsorgsdepartementet, 2014

4. Horn M. Vi trenger ikke aktiv dødshjelp for å sikre pasientene våre en verdig død. www.tv2.no/a/5213844 (8.5.2014).

5. Reinlie S, Hanoa R, Robertsen A et al. Kritiske beslutninger om behandlingsnivå ved alvorlig traumatisk hjerneskade. I: Hanoa R, red. Nevrotraumatologi. Bergen: Fagbokforlaget, 2013.

6. Helsedirektoratet. Nasjonal veileder for beslutningsprosesser for begrensning av livsforlengende behandling hos alvorlig syke og døende. IS-1691. Oslo: Helsedirektoratet, 2009

7. Helse- og omsorgsdepartementet. Høring - forslag til endring i forskrift om dødsdefinisjonen i relasjon til transplantasjonsloven. Oslo: Helse- og omsorgsdepartementet, 2013 